\title{
Emissions of flue gas during pulverized combustion of coal and waste woody biomass
}

\author{
Nihad Hodzic ${ }^{1 *}$, Anes Kazagic ${ }^{2}$, and Kenan Kadic ${ }^{2}$ \\ ${ }^{1}$ University of Sarajevo, Faculty of Mechanical Engineering Sarajevo, 71000 Sarajevo, Bosnia and Herzegovina \\ ${ }^{2}$ JP Elektroprivreda BiH d.d. - Sarajevo Power utility, 71000 Sarajevo, Bosnia and Herzegovina
}

\begin{abstract}
In this paper results of research of co-firing coals from Middle Bosnian basin with waste woody biomass are presented. The research was conducted in the laboratory at the Faculty of Mechanical Engineering in Sarajevo. Tested fuels were subjected to pulverized combustion under various temperatures and various technical and technological conditions: different mass ratio of fuel components in the mixture, different coefficient of excess air for combustion, classic and staged air supply, and fuel staged into the reaction zone. The results are related to the emission of flue gas components with respect to the technological conditions of combustion. In addition to the valorization of the influence of the primary fuel composition and process temperature on the emission values of the flue gas components, it has been shown that the application of primary measures in the combustion chamber results in lower or higher positive effects in terms of reducing the emissions of individual components - e.g. the $\mathrm{NO}_{\mathrm{x}}$ emission is reduced from 837 $\mathrm{mg} / \mathrm{m}_{\mathrm{n}}{ }^{3}$ in conventional combustion to $710 \mathrm{mg} / \mathrm{m}_{\mathrm{n}}{ }^{3}$ using air staging, while during combustion with fuel staging, the NOx emission is reduced in proportion to the part of the fuel that is introduced into the reaction zone subsequently.
\end{abstract}

\section{Introduction}

There are significant coal deposits and reserves in Bosnia and Herzegovina. The conversion of primary energy from this fossil fuel in thermal power plants produces about $75 \%$ of total electricity production. The balance and exploitation reserves of coal in Bosnia and Herzegovina are about $4.5 \cdot 10^{9} \mathrm{t}$, of which about $40 \%$ refers to brown coal and about $60 \%$ to lignite, [1]. However, the quality of Bosnian coal varies significantly from one mining basin to another, and even from one mine to another within the same mining basin. The basic characteristics of these coals are low heating value, high mineral mass and moisture content and poor reactivity, [2]. Consequently, various technical and technological problems arise in the combustion of these coals, including instability and discontinuation of the combustion process. The instability of the combustion process, as well as the level of emissions - especially $\mathrm{NO}_{\mathrm{x}}$ emissions - is directly related to the way and place of introduction of combustion air. Coals from Middle Bosnian mining basin (e.g. Kakanj, Breza and Zenica mines) are predominantly delivered to Thermal Power Plant Kakanj in which it is fired in pc boilers with slag tap furnace. It is well known that this combustion technology is characterized by high temperature in the furnace, especially in the melting chamber (e.g. $1300 \div 1550{ }^{\circ} \mathrm{C}$ ), which results in very high emissions: emission of $\mathrm{NO}_{\mathrm{x}}$ is up to $900 \mathrm{mg} / \mathrm{m}_{\mathrm{n}}{ }^{3}$, while $\mathrm{SO}_{2}$ emission is about $8000 \mathrm{mg} / \mathrm{m}_{\mathrm{n}}{ }^{3}$ due to the content of sulfur in coal mixtures of about $2.5 \%$, [3].
In the near future, due to the necessary transition of the energy sector in the direction of decarbonization and the use of renewable and alternative energy sources, it is necessary to rush in that direction. Especially because the Bosnia and Herzegovina has significant energy potential from waste biomass derived from agricultural production and forestry, primary and secondary wood processing. It is estimated that the total annual technical energy potential of biomass remains in $\mathrm{BiH}$ is more than $33 \mathrm{PJ}$, which is equivalent to more than 3 million tons of BIH lignite, [4].

In principle, a significant reduction in $\mathrm{CO}_{2}$ emissions from coal-fired power plants can be achieved by introducing waste wood biomass as a renewable energy source into regular operation, while the reduction of $\mathrm{NO}_{\mathrm{x}}$ emissions relative to conventional combustion systems can be sufficiently achieved by the use of burners of the newer generation (Low- $\mathrm{NO}_{\mathrm{x}}$ Burner, LNB), staged air supply (OFA), staged primary fuel intake into the furnace and using additional fuel (e.g. natural gas, reburning technology). LNB burners work on the principle of a staged combustion air supply at the single burner level - these burners result in a significant reduction in $\mathrm{NO}_{\mathrm{x}}$ emissions and as such today they are the essential equipment of newer boilers, which usually work with supercritical or ultra-supercritical steam parameters and high flexibility is required, [5]. In the paper [6], the results i.e. effects of the staged supply of combustion air on the $\mathrm{NO}_{\mathrm{x}}$ emission (dried lignite was used as fuel), were presented. It has been shown that in this way there is a significant reduction in $\mathrm{NO}_{\mathrm{x}}$ emission

\footnotetext{
* Corresponding author: hodzic@ mef.unsa.ba
} 
- the results are related to the investigation of the influence of the coefficient of excess air, the distribution of combustion air, and the distance of the position of introduction of the OFA air into the reaction zone relative to the burner. In the paper [7] it was stated that, with Low- $\mathrm{NO}_{\mathrm{x}}$ burners, the $\mathrm{NO}_{\mathrm{x}}$ emission can be reduced by a fifth, but that due to the high combustion temperature this emission is still high $\left(1036 \mathrm{mg} / \mathrm{m}_{\mathrm{n}}{ }^{3}\right.$ in dry flue gases with $6 \% \mathrm{O}_{2}$ ), and for the further reduction of $\mathrm{NO}_{\mathrm{x}}$ emissions, a zonal or staged combustion air supply (OFA) is recommended. Similar positive effects of the staged supply of combustion air on the reduction of $\mathrm{NO}_{\mathrm{x}}$ emissions are presented in works [8] and [9] for coal combustion; as well as for co-firing coal with biomass, [10-15].

By subjecting coal blends, as well as mixtures of coal and waste woody biomass, to combustion at different temperatures with the application of staged combustion air supply as primary measure, and with the introduction of a portion of the OFA air at different distances from the primary burner, it is possible to determine the appropriate response of the combustion process through the measurement of process parameters and their analysis, i.e. it is possible to come to relevant conclusions about the characteristics of combustion and consequently the influence of various influencing factors on the emission of flue gas components into the environment, e.g. $\mathrm{CO}_{2}, \mathrm{CO}, \mathrm{NO}_{\mathrm{x}}$ and $\mathrm{SO}_{2}$. Based on these conclusions, it is possible to quantify and sublimate the combustion characteristics of coal and wood biomass, including the advantages of conversion of primary energy from fuels under conditions of solid fuel pulverized combustion technology with a staged combustion air supply, [16]. Wood biomass residues subjected to toreification are very suitable for cocombustion with coal in existing thermal power plants due to their increased net heat capacity, [18], where such an aspect of wood biomass application is significant in terms of reducing $\mathrm{CO}_{2}$ emissions into the environment, [19].

\section{Fuel test matrix, test regimes and laboratory plant}

Fuel Test Matrix and Test Regimes: For the purpose of laboratory investigations of the influence of the staged supply air and fuel staged into the furnace while cofiring coal with waste woody biomass on the emission of the flue gas components, a matrix of basic test fuels was established, [16] - Table 1.:

- The usual coal blend that has been fired in TPP Kakanj for the last few years - fuel label: U100. This coal blend was produced by mixing coals delivered to the coal depot of TPP Kakanj from several mines (Kakanj, Breza, Zenica, Gracanica, Livno, Nova Bila, Banovići, etc.) in approximately the same percentage as they are delivered from the mentioned mines. For laboratory testing purposes a sample of this coal mixture (coal powder) is excluded directly behind the mills during real operation of the Unit 5 in TPP Kakanj.
- Wood biomass sawdust - fuel label: B100. Sawdust is a mixture of beech and spruce formed during primary wood processing, in an approximate 50:50 weight ratio. The sawdust sample was excluded after delivery to the TE Kakanj depot.

- Mixture made of U100 coal blend and waste wood biomass B100 - fuel label: U95B5 and U93B7. These mixtures consist of 5 and $7 \%$ wood biomass respectively and are excluded behind the mills.

- Mixture made of coal U100 and waste wood biomass B100 - fuel label: U90B10. This coal mixture consists of $10 \%$ wood biomass and is formed after drying and grinding the components in a laboratory mill.

The mentioned solid fuels (mixtures of coal and biomass) were subjected to a laboratory investigation of combustion under the conditions of staged supply of combustion air and fuel into the combustion chamber. Test regimes are defined and performed in the range of process temperatures corresponding to the temperatures from the real boiler operation in TPP Kakanj: $1350 \div 1450{ }^{\circ} \mathrm{C}$. A set of these research was aimed at gaining insight into the characteristics of co-firing coal with biomass, with a particular emphasis on emissions of flue gas components, primarily $\mathrm{NO}_{\mathrm{x}}$.

Table 1. Basic properties of test fuel, [16]

\begin{tabular}{|c|c|c|c|c|c|}
\hline Fuel & $\mathrm{U} 100$ & $\mathrm{~B} 100$ & U95B5 & U93B7 & U90B10 \\
\hline \multicolumn{6}{|c|}{ Proximate analysis, $\%$} \\
\hline Moisture & 13,90 & 21,63 & 19,06 & 18,09 & 14,67 \\
\hline Ash & 37,88 & 0,52 & 34,33 & 33,05 & 34,14 \\
\hline Volatiles & 28,97 & 64,14 & 29,32 & 31,16 & 32,49 \\
\hline $\mathrm{C}_{\mathrm{fix}}$ & 19,25 & 13,72 & 17,28 & 18,59 & 18,70 \\
\hline Combustible & 48,22 & 77,86 & 46,60 & 48,86 & 51,18 \\
\hline \multicolumn{6}{|c|}{ Utimate analysis, \% } \\
\hline Carbon & 36,62 & 38,92 & 32,12 & 33,36 & 33,25 \\
\hline Hxdrogen & 2,60 & 4,95 & 2,20 & 2,52 & 2,84 \\
\hline Sulfur & 2,06 & 0,14 & 1,57 & 1,59 & 1,87 \\
\hline Nitrogen & 0,72 & 0,17 & 0,81 & 0,75 & 0,67 \\
\hline Oxygen & 10,22 & 33,67 & 9,91 & 10,63 & 12,57 \\
\hline \multicolumn{6}{|c|}{ Heating values, $\mathrm{kJ} / \mathrm{kg}$} \\
\hline HHV & 13351 & 15564 & 12651 & 13446 & 13572 \\
\hline LHV & 12496 & 14081 & 11759 & 12510 & 12655 \\
\hline
\end{tabular}

Laboratory plant: Automatic Controlled Tube Reactor (AUCR) was installed at Faculty of Mechanical Engineering of University in Sarajevo, Department of energy, and allows testing the combustion characteristics of different fuels at different ambient and technological conditions, Figure 1, while the principal scheme of the experimental furnace with the indicated distribution of air and fuel staging for combustion is given in [16]. Briefly, the plant is designed to operate in a wide temperature range (from ambient temperature to $1560{ }^{\circ} \mathrm{C}$ ) and in conditions of different amount and distribution of basic fuel and air combustion, including the possibility of testing reburning combustion technologies using additional fuel, such as natural gas. Basically, the research provides data related to combustion efficiency, deposition intensity and characteristics of deposits from the reaction zone as well as slag and ash at the reactor outlet, and emissions of 
flue gas components: $\mathrm{O}_{2}, \mathrm{CO}, \mathrm{CO}_{2}, \mathrm{NO}, \mathrm{NO}_{2}, \mathrm{NO}_{\mathrm{x}} \mathrm{i}$ $\mathrm{SO}_{2},[16]$.

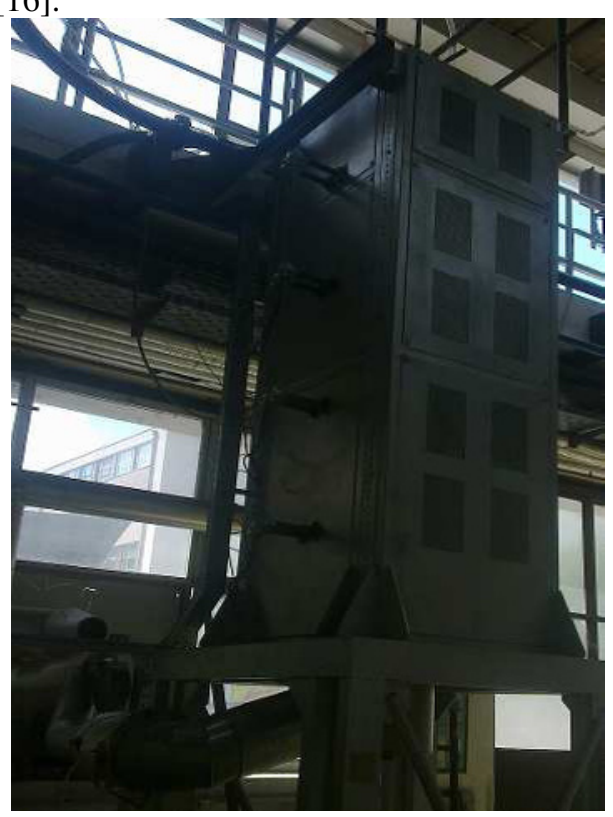

Figure 1. AUCR experimental line: front view of four visible zones with temperature measurement of the reaction tube and process control

\section{Results of the research: Emission of flue gas components}

Air staging: For the same combustion temperature, $\mathrm{NO}_{\mathrm{x}}$ emission in co-firing was found to be at the same emission level as for combustion of coal without biomass, and that there is practically no change in that emissions with the change in the fraction of wood biomass in the mixture. The average $\mathrm{NO}_{\mathrm{x}}$ emission difference depending on the mode of supply of combustion air is $250 \mathrm{mg} / \mathrm{m}_{\mathrm{n}}{ }^{3}$ : in the case of conventional air supply, the average $\mathrm{NO}_{\mathrm{x}}$ emission is $942 \mathrm{mg} / \mathrm{m}_{\mathrm{n}}{ }^{3}$, while in the case of a stage combustion air supply, the emission is $692 \mathrm{mg} / \mathrm{m}_{\mathrm{n}}{ }^{3}$, Figure 2 .

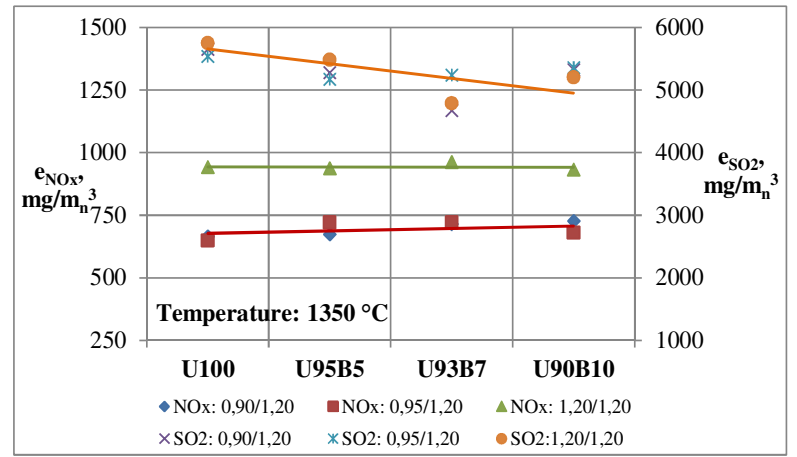

Figure 2. Emission of $\mathrm{NO}_{\mathrm{x}}$ and $\mathrm{SO}_{2}$ in the co-firing of coal with woody biomass at process temperature of $1350{ }^{\circ} \mathrm{C}$

On the other hand, the sulfur content decreases proportionally with the increase of fraction of wood biomass in the coal mixture. Despite the fact that the results regarding $\mathrm{SO}_{2}$ emission are dispersed, it can still be concluded that the $\mathrm{SO}_{2}$ emission reduces proportionally with the increase in biomass content in the mixture. Additionally, based on the results of the measurements, it can be concluded that the $\mathrm{SO}_{2}$ emission practically does not depend on the way of combustion air supply - that emission is high and at a process temperature of $1350{ }^{\circ} \mathrm{C}$ it is approximately 5300 $\mathrm{mg} / \mathrm{m}_{\mathrm{n}}{ }^{3}$, Figure 2. Total and net $\mathrm{CO}_{2}$ emission due to the combustion of wood biomass as a renewable fuel in a coal mixture is presented in Figure 3. Increasing the fraction of woody biomass in the mixture linearly reduces the net $\mathrm{CO}_{2}$ emission, which at $10 \%$ of biomass in the mixture is $0.233 \mathrm{~kg} / \mathrm{m}_{\mathrm{n}}{ }^{3}$. Somewhat more pronounced $\mathrm{CO}$ emissions from co-firing of coal with biomass, especially at $10 \%$ of the biomass content, compared to the combustion of coal, can be related to the granulation of woody biomass in the mixture that is not mechanically treated (not grinded in the laboratory mill) - a certain fraction of biomass particles was up to $4 \mathrm{~mm}$, Figure 3.

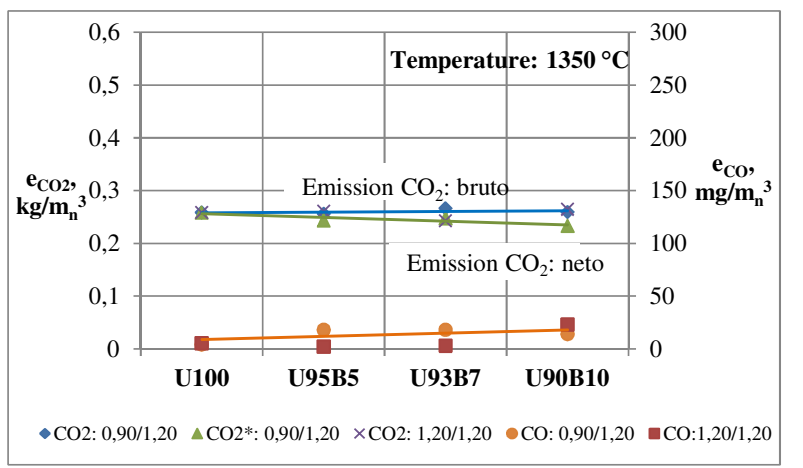

Figure 3. Emission of $\mathrm{CO}_{2}$ and $\mathrm{CO}$ in the co-firing of coal with woody biomass at process temperature of $1350{ }^{\circ} \mathrm{C}$

With the increase of combustion temperature, $\mathrm{NO}_{\mathrm{x}}$ and $\mathrm{SO}_{2}$ emissions are also increasing. For example, at temperature of $1450{ }^{\circ} \mathrm{C}$ the average $\mathrm{NO}_{\mathrm{x}}$ emission is 800 $\mathrm{mg} / \mathrm{m}_{\mathrm{n}}{ }^{3}$ and the $\mathrm{SO}_{2}$ emission is about $5200 \mathrm{mg} / \mathrm{m}_{\mathrm{n}}{ }^{3}$, Figure 4. In these test regimes, the previously stated conclusions were confirmed that the $\mathrm{NO}_{\mathrm{x}}$ emissions practically do not change with the increase in the fraction of wood biomass in the mixture, and that the $\mathrm{SO}_{2}$ emission decreases proportionally by this increase of biomass fraction in the mixture - Figure 4 .

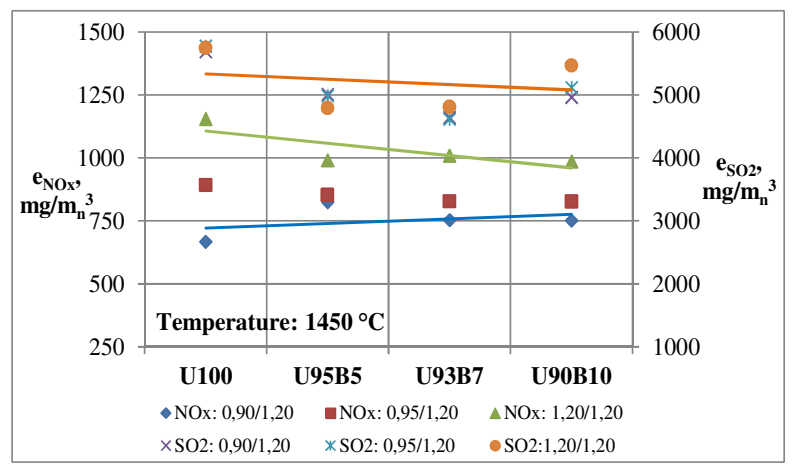

Figure 4. Emission of $\mathrm{NO}_{\mathrm{x}}$ and $\mathrm{SO}_{2}$ in the co-firing of coal with woody biomass at process temperature of $1450{ }^{\circ} \mathrm{C}$

Fuel staging: Emission $\mathrm{NO}_{\mathrm{x}}$ during basic fuel staging at process temperature of $1350{ }^{\circ} \mathrm{C}$ and for two values of 
the percentage share of the basic fuel staging into the chamber ( 5 and $10 \%$ by mass), Figure 5. In general, there is a reduction emission. Emission $\mathrm{NO}_{\mathrm{x}}$, during basic fuel staging at $5 \%$, is on average $630 \mathrm{mg} / \mathrm{m}_{\mathrm{n}}{ }^{3}$ or about $5 \%$ (relative) lower than the smission from combustion withoout fuel staging. Emission $\mathrm{NO}_{\mathrm{x}}$, during basic fuel staging at $10 \%$, is on average 570 $\mathrm{mg} / \mathrm{m}_{\mathrm{n}}{ }^{3}$, which represents an average reduction in emission $\mathrm{NO}_{\mathrm{x}}$ of almost $100 \mathrm{mg} / \mathrm{m}_{\mathrm{n}}{ }^{3}$ or by close to $15 \%$ (relative), [16-17] - Figure 5.

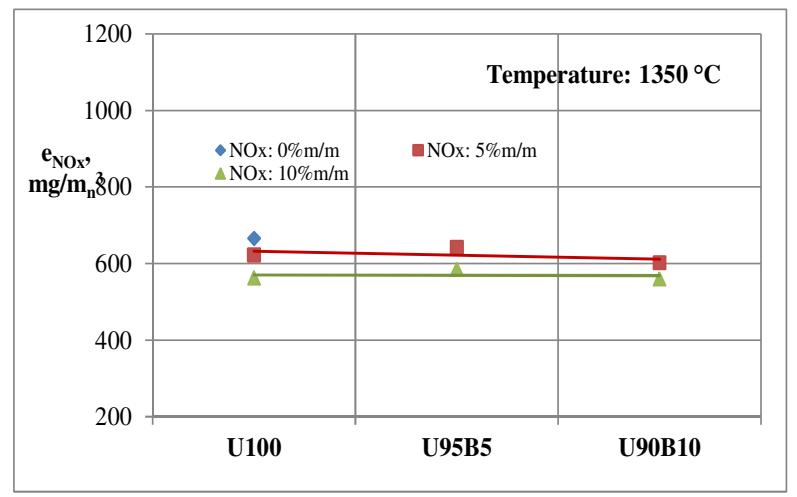

Figure 5. Emission $\mathrm{NO}_{\mathrm{x}}$ during fuel staging of different composition in the same process conditions

Effects of the application of $10 \%$ fuel staging on emission $\mathrm{NO}_{\mathrm{x}}$, depending on the process temperature for fuels of different composition are presented in Figure 6.

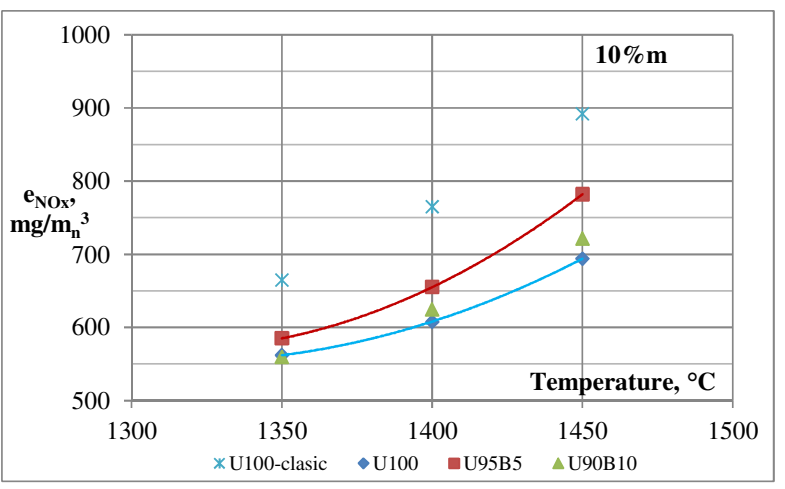

Figure 6. Effect of process temperature on emission $\mathrm{NO}_{\mathrm{x}}$ during fuel staging for different fuel

The effect basic fuel staging to the reaction zone on emission $\mathrm{SO}_{2}$ is presented in Figure 7. These emission, recorded in the test regimes for different fuels and during 5 and $10 \%$ fuel staging, are practically at the level emission $\mathrm{SO}_{2}$ in case of combustion without fuel staging (U100, 0\% $)$ - on average, this emission is around $5500 \mathrm{mg} / \mathrm{m}_{\mathrm{n}}{ }^{3}$ for both tested percentages of fuel staging, [16-17].

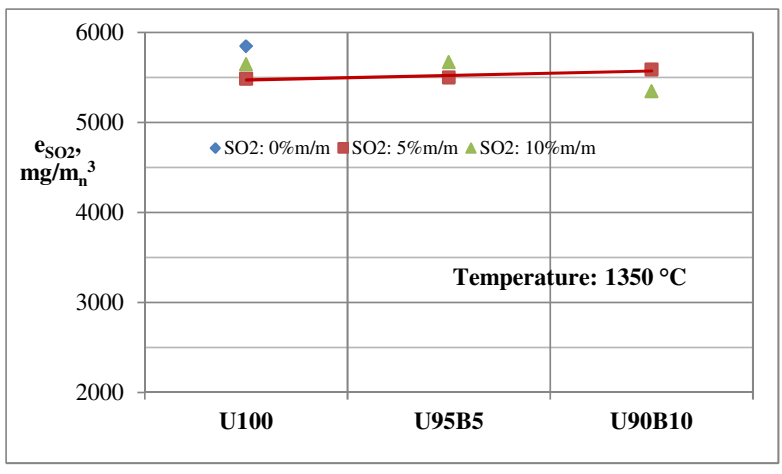

Figure 7. Emission $\mathrm{SO}_{2}$ during fuel staging and different fuel in the same process conditions

However, it should be noted than bacin fuel staging, there is a significant increase emission $\mathrm{CO}$ obtained by combustion without fuel staging - they compare the values of $\mathrm{CO}$ emissions obtained by combustion the same fuel, at the same temperature, the same coefficient of excess air for combustion and the mode of supply of that air. The reason for this is the shorter combustion parh of fuel particles (coal and/or biomass) which is subsequently introduced into the combustion zone. In this case, the available combustion path is about $2 / 3$ of the combustion path of the fuel participle introduced directly to the burner. This emission $\mathrm{CO}$ is quite high even at higher temperatures, for example at a temperature of $1450{ }^{\circ} \mathrm{C}$ it is over $200 \mathrm{mg} / \mathrm{m}_{\mathrm{n}}{ }^{3}$, [16].

The obtained results are very important in the design of new but also in the reconstruction of existing boilers in terms of the introduction of fuel staging - it is obvious that the advantages fuel staging in terms of reducing emission $\mathrm{NO}_{\mathrm{x}}$ are usually accompanied by potential disadvantages reflected in increased emission Co in flue gases and increased content of combustible substances in slag and ash during these combustion regimes. This shows that the choice of the place of subsequent introduction fuel staging is very important and has the opposite effect in temrs of emission $\mathrm{NO}_{\mathrm{x}}$ and combustion efficiency: for example, at a combustion temperature of $1350{ }^{\circ} \mathrm{C}$ emission $\mathrm{NO}_{\mathrm{x}}$ is reduced by $15 \%$ (relative) and emission $\mathrm{CO}$ increased by more than 20 times with fuel staging, for fuel U100 on 1/3 of the chamber height, Figure 8.

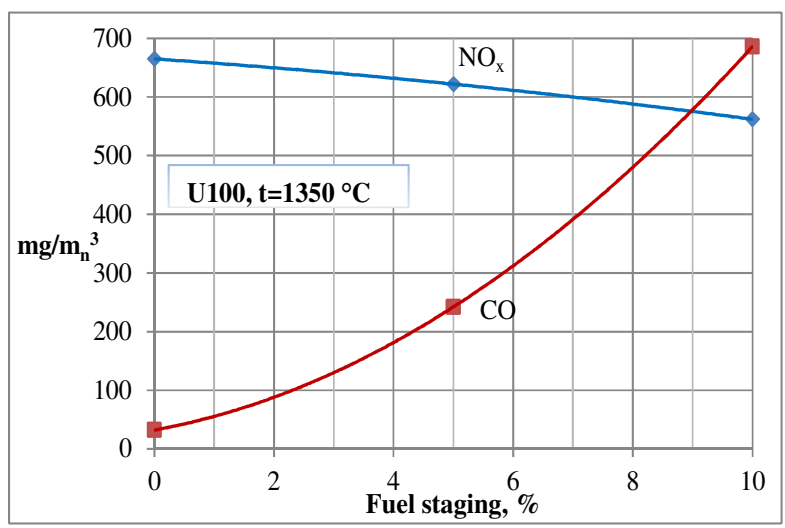

Figure 8. Increase emission $\mathrm{CO}$ with the share of fuel staging 
The $\mathrm{NO}_{\mathrm{x}}$ emission for co-firing coal with biomass (U95B5) with the application of different primary measures in the combustion chamber (air and/or fuel staging), including the efficiency of these measures by reducing this emissions relative to those in conventional combustion, is presented in Figure 9. - the results refer to the combustion temperature of $1450{ }^{\circ} \mathrm{C}$.

By analyzing the obtained results, e.g. presented in the previous Figure 6, it is concluded that the efficiency of the primary measure basic fuel staging weakens with increasing process temperature. Namely, the efficiency basic fuel staging at a temperature of $1450{ }^{\circ} \mathrm{C}$ is almost $21 \%$ (Figure 9) compared to $32 \%$ at a temerature of $1350{ }^{\circ} \mathrm{C}$, while the difference in the efficiency of the application combustion air staging for the observed temperatures is the smallest.

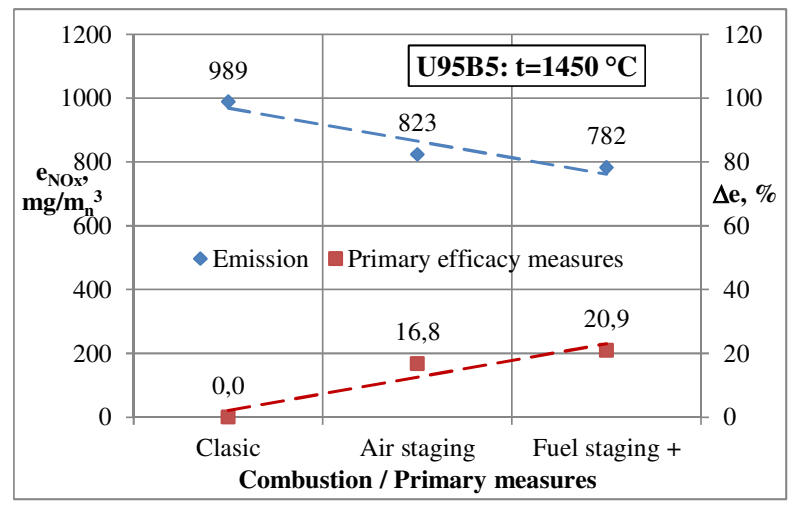

Figure 9. Eficiency of primary measures at the combustion temperature of $1450{ }^{\circ} \mathrm{C}$, fuel: U95B5

\section{Conclusion}

Based on the results of the research, the following conclusions can be drawn regarding the impact of various factors on the emission of flue gas components in the co-firing of coal with waste woody biomass during air staging:

- $\mathrm{NO}_{\mathrm{x}}$ emissions in co-firing coal with waste woody biomass is at the emission level at combustion of coal blend. There is practically no change in this emission with the change in the fraction of woody biomass in the mixture. The average difference in $\mathrm{NO}_{\mathrm{x}}$ emissions depending on the mode of combustion air is 250 $\mathrm{mg} / \mathrm{m}_{\mathrm{n}}{ }^{3}$ : for the classical air intake the average emission is about $940 \mathrm{mg} / \mathrm{m}_{\mathrm{n}}{ }^{3}$, while for the mode with air staging it is about $690 \mathrm{mg} / \mathrm{m}_{\mathrm{n}}{ }^{3}$.

- the $\mathrm{SO}_{2}$ emission is slightly reduced by increasing the fraction of woody biomass and practically does not depend on the mode of combustion air intake - the emissions are high and generally over $5000 \mathrm{mg} / \mathrm{m}_{\mathrm{n}}{ }^{3}$,

- by increasing the fraction of woody biomass in the mixture, the $\mathrm{CO}_{2}$ (net emission) is proportionally reduced, which at the $10 \%$ biomass in the mixture is $0.233 \mathrm{~kg} / \mathrm{m}_{\mathrm{n}}{ }^{3}$,

that is, during fuel staging:

- emission $\mathrm{NO}_{\mathrm{x}}$ during basic fuel slaging is reduced this reduction is proportional to the part of the fuel that is introduced into the reaction zone subsequently, e.g. emission $\mathrm{NO}_{\mathrm{x}}$, during basic fuel staging at $10 \%$, and process temperature of $1350{ }^{\circ} \mathrm{C}$ is reduced almost average by about $100 \mathrm{mg} / \mathrm{m}_{\mathrm{n}}{ }^{3}$ or by close to $15 \%$ in related to the emission from combustion without fuel staging,

- as the combustion temperature increases, the efficiency of this primary measure in terms of emission $\mathrm{NO}_{\mathrm{x}}$ decreases. For example, at a temperature of $1450{ }^{\circ} \mathrm{C}$ and for fuel U100, this emission is reduced from about $890 \mathrm{mg} / \mathrm{m}_{\mathrm{n}}{ }^{3}$ to about $690 \mathrm{mg} / \mathrm{m}_{\mathrm{n}}{ }^{3}$ or by over $22 \%$ (relative) in relation to the emission at the same temperature, quantity and mode of air supply but without fuel staging,

- combustion during basic fuel slaging, there is a significant increase in the $\mathrm{CO}$ content in the flue gases, for example for fuel U100: $686 \mathrm{mg} / \mathrm{m}_{\mathrm{n}}{ }^{3}$ at 1350 ${ }^{\circ} \mathrm{C}$ and $140 \mathrm{mg} / \mathrm{m}_{\mathrm{n}}{ }^{3}$ at $1450{ }^{\circ} \mathrm{C}$ - this phenomenon requires finging the optimal solution that will make the combustion process economically viable and environmentally acceptable through $\mathrm{NO}_{x}$ i $\mathrm{CO}$ emission levels, which means finding the best ration of fuel slaging into the combustion zone (\%), on the one hand, and the place of introduction of the part of fuel slaging in relation to the primary zone combustion, or burner, and

- emission $\mathrm{SO}_{2}$, recorded in test regimes for different fuel, with 5 i $10 \%$ fuel staging, is practically at the level of emission $\mathrm{SO}_{2}$ in case of combustion without fuel staging - on average this emission is about 5500 $\mathrm{mg} / \mathrm{m}_{\mathrm{n}}{ }^{3}$ for both cases fuel staging.

Part of the results presented in this paper were created during the research in the framework of the two projects:

- Advantages of co-firing of coal with waste wood biomass under the conditions of staged air supply,

financed by the Ministry of Education and Science of the Federation of Bosnia and Herzegovina for 2018., and

- Expanding research activities and opportunities use of biomass through Clean Coal Technologies, as part of the European Green Deal challenges,

Financed by Ministry of Civil Affairs of Bosnia and Herzegovina for 2020.,

and infrastructural assisted by the Faculty of Mechanical Engineering of Universtity of Sarajevo, and in this paper all of them deserve acknowledgements for the support.

\section{References}

[1] Studija energetskog sektora u $\mathrm{BiH}$, Konačni izvještaj, Modul 8 - Rudnici uglja, Konzorcij: Energetski institut Hrvoje Požar, Hrvatska; Soluziona, Španjolska; Ekonomski institut Banjaluka, BiH; Rudarski institut Tuzla, BiH, 2009.

[2] Uticaj kvaliteta uglja na troškove proizvodnje električne energije $i$ cijenu uglja; Studija; Naručilac: JP Elektroprivreda BiH d.d. Sarajevo, Izvršilac: Mašinski fakultet Sarajevo (Lider) i Rudarski institut d.d. Tuzla (član), Sarajevo, 2014.

[3] Smajević I., Hodžić N.: Betriebserfahrungen im Kraftwerk Kakanj bei der Verbrennung der starkverschmutzungsneigenden mitelbosnischen 
Braun-kohle, Dresden, 25.-26. Oktobar 2000., 151160,

[4] Advanced Decentralised Energy Generation Systems in Western Balkans - ADEG, Project FP6, National Technical University of Athens, Institut IVD Stuttgart, Fakultet Strojarstva i Brodogradnje Zagreb, Mašinski fakultet Sarajevo, Institut Vinča, IST Portugal, voditelj projekta ispred MF Sarajevo: A. Lekić, podprojekat: Biomasa, voditelj podprojekta: I. Smajević, član istraživačkog tima: N. Hodžić, i dr., 2004.-2007.

[5] Tsumura T., Okazaki H., Dernjatin P., Savolainen $\mathrm{K}$., Reducing the minimum load and $\mathrm{NO}_{x}$ emissions for lignite-fired boiler by applying a stable-flame concept, Applied Energy, Volume 74, Issues 3-4, March-April 2003, p. 415-424.

[6] Wang J., Fan W., Li Y., Xiao M., Wang K., Ren P., The effect of air staged combustion on $N O_{x}$ emissions in dried lignite combustion, Energy, Volume 37, Issue 1, January 2012, p. 725-736.

[7] Kuang M., Li Z., Liu C., Zhu Q., Experimental study on combustion and $\mathrm{NO}_{x}$ emissions for a downfired supercritical boiler with multiple-injection multiple-staging technology without overfired air, Applied Energy, Volume 106, June 2013, p. 254261.

[8] Kuang M., Li Z., Ling Z., Zeng X., Evaluation of staged air and overfired air in regulating airstaging conditions within a large-scale down-fired furnace, Applied Thermal Engineering Volume 67, Issues 1-2, June 2014, p. 97-105.

[9] Rozendaal M. Impact of coal quality on $N O_{x}$ emissions from power plants. Delft: Delft University of Technology, 1999.

[10] Kazagić A. Smajević I.: Experimental investigation of ash behaviour and emissions during combustion of Bosnian coal and biomass, Energy, Volume 32, Issue 10 (October 2007), p. 2006-2016.

[11] Kazagić A., Smajević I., Synergy Effects of Cofiring of Wooden Biomass with Bosnian Coal, Energy, Volume 34, Issue 5 (May 2009), p. 699707.

[12] Kazagić A., Smajević I., Duić N., Selection of sustainable technologies for combustion of Bosnian coals, Thermal Science, Volume 14, No. 3 (2010), p. 715-727.

[13] Smajević I., Kazagić A., Musić M., Bečić K., Hasanbegović I., Sokolović Š., Delihasanović N., Skopljak A., Hodžić N., Co-firing Bosnian Coals with woody biomass: experimental studies on a laboratory-scale furnace and $110 \mathrm{MW}$ power unit, Thermal Science, 16 (2012), 3, p. 789 - 804.

[14] Nareddy S., Moyeda D., Zhou W., Marquez A., Swanson L., Duval S., NOx reductions Achieved Through Air Staging in Cyclone Fired Boilers, 32. International Clearwater Coal Conference, Clearwater, Florida, USA, 01.06. - 05.06. 2008.

[15] Hodzic N., Kazagic A., Kadic K., Air Staging and reburning to Achieve Low Emissions During Cofiring Coal and Biomass, New Technologies - NT
2020, Development and Application III pp 657 666, Sarajevo, Bosnia and Herzegovina, June 2527. 2020

[16] Hodžić, N., Istraživanje kosagorijevanja uglja $i$ biomase usmjereno na smanjenje emisija primarnim mjerama $u$ ložištu, Doktorska disertacija, Mašinski fakultet Univerziteta $u$ Sarajevu, Sarajevo, 2016.

[17] Hodžić, N., Kazagić, A., Smajević, I., Influence of multiple air staging and reburning on $N O_{x}$ emissions during co-firing of low rank brown coal with woody biomass and natural gas, Applied Energy 168, 2016., p. 38-47,

http://dx.doi.org/10.1016/j.apenergy.2016.01.081

[18] Falah Alobaid, Jan-Peter Busch, Alexander Stroh, Jochen Ströhle, Bernd Epple, Experimental measurements for torrefied biomass Cocombustion in a $1 \mathrm{MW}_{\text {th }}$ pulverized coal-fired furnace, Journal of the Energy Institute Volume 93, Issue 3, June 2020, Pages 833-846, https://doi.org/10.1016/j.joei.2019.07.008

[19] Sujeet Yadav, Swasti Sundar Mondal, A complete review based on various aspects of pulverized coal combustion, International Journal of Energy Research, First published: 14 February 2019, https://doi.org/10.1002/er.4395 